Meta

Journal des traducteurs

Translators' Journal

ANGelelLi, Claudia V. and Brian James BAER, eds. (2016): Researching Translation and Interpreting. London/New York: Routledge, $291 \mathrm{p}$.

\title{
Andrew Chesterman
}

Volume 61, numéro hors-série, 2016

URI : https://id.erudit.org/iderudit/1038692ar

DOI : https://doi.org/10.7202/1038692ar

Aller au sommaire du numéro

Éditeur(s)

Les Presses de l’Université de Montréal

\section{ISSN}

0026-0452 (imprimé)

1492-1421 (numérique)

Découvrir la revue

Citer ce compte rendu

Chesterman, A. (2016). Compte rendu de [ANGELELLI, Claudia V. and Brian James BAER, eds. (2016): Researching Translation and Interpreting. London/New York: Routledge, 291 p.] Meta, 61,176-178. https://doi.org/10.7202/1038692ar services d'Érudit (y compris la reproduction) est assujettie à sa politique d'utilisation que vous pouvez consulter en ligne.

https://apropos.erudit.org/fr/usagers/politique-dutilisation/ 


\section{DOCUMENTATION}

\section{Comptes rendus}

Angelelli, Claudia V. and Brian James Baer, eds. (2016): Researching Translation and Interpreting. London/New York: Routledge, 291 p.

Standing somewhere between a collection of encyclopedia or handbook articles and a general introductory survey of the field, this book is an interesting contribution to current attempts to grasp, and also to guide, the development of our interdiscipline. It is both a richly sourced reference book on current research areas and methods, and an argument for a particular general view of Translation and Interpreting Studies (TIS). It covers both translation and interpreting, and gives good space to theories developed outside TIS itself.

The book opens with a short introductory chapter by the editors on "Exploring translation and interpreting," constituting, by itself, Part I of the volume. This is where we find the rationale of the collection, and the overall framework of the argument. The editors advocate a post-structuralist approach, arguing against "essentialist" views based on "traditional positivist concepts" such as equivalence and fidelity. Some of this argument seems to me to be directed against straw men. Is it really true that TIS has up to now been focused, for example, on "inaccuracies in communication" and has overlooked "fundamental questions regarding access to comunication" (p. 5)? The importance of a reflexive research practice, of questioning traditional categories, acknowledging that all communication is context-bound, and avoiding unjustified "universalizing," is surely not recognized exclusively by post-structuralists. "Positivist" concepts of representation may certainly need modifying in many contexts of research and practice, but mimetic representation is far from being irrelevant to medical, legal and technical translation, for instance, or to terminological work. Equivalence, fidelity and neutrality are values that serve usefully as regulative ideas in many T\&I contexts.

The authors claim that "resistance to the post-structuralist understanding of the relationship of language to meaning, i.e. that meaning is constructed in the act of interpretation, remains strong" (p. 8-9). Two objections can be made here. One is that meaning is not necessarily either represented or constructed: we are not faced with an binary (essentialist?) choice here. In some contexts much construction of meaning may be needed, in others less. The second, more fundamental, objection is that neither positivism nor poststructuralism are empirical truths or agreed facts, but interpretations of (aspects of) reality. As such, they are not claims that can be proved to be either right or wrong, but views that may be adopted or rejected on grounds of pragmatic usefulness or e.g. ideological preference, and of course by weighing up the evidence for and against them. More generally, I think the editors' assumption of a binary opposition between the paradigm of the hard sciences and that of the humanities is already history. For instance, quantum physicists accept that in some situations the observer can apparently affect the object observed, and humanists can easily accept that in some situations some meanings are more fixed and universal than in others.

Part II, "Mapping the field," consists of 11 short chapters by different specialists on research areas the editors see as central to current and future TIS. They are arranged in alphabetical order: Agency and role; Bilingualism and multilingualism; Cognitive processes; Collaborative and volunteer translation and interpreting; Fictional representations of translators and interpreters; Gender and sexuality; History and historiography; Translation and interpreting pedagogy [which would be alphabetically better as Pedagogy of T\&I]; Power and conflict; Profession, identity and status; Reader response and reception theory. Any such unstructured list is of course selective, and these topics can reasonably well illustrate the thrust of the anti-essentialist argument. However, other topics might also be seen as current in modern TIS, such as adaptation studies, contrastive textual analysis, work on translation memories or translation aids, or terminology and language policy.

Each chapter has the same helpful structure: Overview, Theoretical foundations, Evolution of the topic in TIS, Key studies, New directions, and References. The reference sections are long, making the volume a useful reference work. The focus is mainly on the development of the research topics themselves, within each area, rather than methodological issues or specific findings. Some chapters introduce interesting conceptual groupings. Jiménez-Crespo, for instance, deals with volunteer translation and interpreting together with collaborative T\&I in general, as opposed to language mediation work by individuals: a fruitful juxtaposition. On the whole, the contributions to this Part are highly informative. Critical attitudes 
are not much in evidence, with some exceptions such as Sela-Sheffy, who warns of the risks of naive questionnaire research. Occasionally, the background theory cited is somewhat narrow: dicussing research on agency, Tyulenev relies heavily on Talcott Parsons, with scarcely a mention of Bourdieu. Here and there, a claim may prompt argument or disagreement. Writing about fictional translators, Kaindl assumes that "our knowledge about the world is ultimately always subjective" (p. 72), an idea that can indeed be debated. He also cites with evident approval another scholar's claim that "we do not experience reality in an immediate way; it is always indirectly mediated through symbols, language, and texts" (p. 75). Always? What kind of small reality is this? And what kind of evidence for the value or validity of a point of view is the fact that someone else happens to agree with it?

Part III comprises 13 short chapters by different contributors on "Research methods." These are also listed alphabetically, as follows: Action research; Bibliometric studies; Case studies; Conversation analysis; Corpus-based studies; Critical discourse analysis; Ethnography of communication; Experimental research; Histoire croisée; Interviews and focus groups; Narrative analysis; Observations [perhaps better in the singular?]; Survey-based studies. Additional possibilities might have been contrastive analysis, conceptual analysis and semiotics, all with long research traditions at least in research on translation. Perhaps mixed-method approaches would also have deserved a chapter. The writers have made good use of background sources outside TIS itself, but some more from within TIS could be added in future editions, such as Susam-Sarajeva (2009) on case studies, and Bowker and Pearson (2002) on corpus studies.

In this Part too, the chapters are similarly structured, with some slight variation: Definition, Origins, Uses, Sample studies, Conclusion and new directions / potential applications, Further reading, References. And here too, the comprehensive reference sections are very useful. Critical views of the various methods discussed are not given much room, with the notable exceptions of the essays by Mason (on critical discourse analysis) and Gile (on experimental research). Mason's discussion of the risk of circular argument is very much to the point. However, I would not agree with him that the conduit model of communication has been "universally rejected" in TIS (p. 205); as suggested above, a conduit model, based on some notion of transferrable meanings, can be relevant and useful in some contexts. I would also question Baker's assumption, concerning the centrality of narrative analysis, that narrative is "the only means by which we experience the world" (p. 247). The only means? Isn't this too a kind of essentialism? The absoluteness of the claim risks losing the reader's acceptance of the more modest, and more persuasive, claim that narrative is one important way of making sense of our experience of the world - compare my comment above, on the similarly dubious universalizing implication of a use of "always."

In Part III, one contribution rather differs from the others: the chapter on Histoire croisée, by Wolf. It does not deal with the methodology of history research in general (which has in fact already been touched on in the Part I chapter on history) but with one particular, and highly complex, approach to historical research. And according to Wolf there have so far been only two T\&I studies which have used this method. Claims concerning its potential relevance to TIS seem rather premature.

There is some overlap between the chapter on survey studies and the one on interviews, which could have been combined. Both cite the work of the social reform activist Charles Booth as a pioneer of survey research, with slightly varying dates. According to the Charles Booth Online Archive ${ }^{1}$, his actual survey work on poverty in London lasted from 1886 to 1903, and was first published in two volumes, in 1889 and 1891. Some eyebrows might be raised at Sun's claim that surveys are "probably the most common empirical research method in the social sciences and the humanities" (p. 269). The humanities too? Evidence? On the other hand, he makes useful critical comments on misunderstandings of Likert scales, and on other methodological weaknesses of questionnaire studies.

Regarding the purely technical side of editing, my eye was caught by a delightful misprint on p. 200, where mention is made of something called the "typo-token ratio," instead of type-token. In fact, the "typo-token" ratio in this volume is impressively low, although future editions should correct the repeated slips (pp. 1 and 4) in the titles of the volume edited by Olohan (2000), which should be Intercultural Faultines: Research Models in Translation Studies I), and the companion volume edited by Hermans (2002), which should be Crosscultural Transgressions: Research Models in Translation Studies II). Better definitions might also be offered for ontology and epistemology (glossed as "what is" and "what we know about what is," p. 6.). Both these are, after all, not collections of facts which are accepted to be true, but branches of philosophy.

Andrew Chesterman University of Helsinki, Helsinki, Finland 


\section{NOTES}

1. Charles Booth Online Archive. London School of Economics \& Political Science. <http:// booth.lse.ac.uk/static/a/3.html>.

\section{REFERENCES}

Bowker, Lynne and Pearson, Jennifer (2002): Working with Specialized Language: A Practical Guide to Using Corpora. London: Routledge.

Susam-Sarajeva, Şebnem (2009): The Case Study Research Method in Translation Studies. The Interpreter and Translator Trainer. 3(1):37-56.

Pennycook, Alastair and Otsuji, Emi (2015): Metrolingualism. Language in the City. Routledge: London/New York, 205 pages.

This is an exciting book. It introduces a new way of thinking about language contact, and a new way of exploring the realities of language in urban life. It is written with enthusiasm for the dynamism of city life in the diverse cities of Sydney and Tokyo. It is somewhat marred by repetition, however, and feels like an accumulation of research notes rather than a fully prepared work of scholarship. Part of this disorder is voluntary, however, as the aim of the project is to highlight the very process of research, not only in terms of the discussions and reflections of the researchers as they visit the shops, cafés, construction sites, markets and restaurants that are their research sites - but also in terms of the large number of sources which are quoted throughout the book. It is perhaps best to think of this book as a collection of notebooks and sketches - as a resource, then, for further work.

The aim of the book is clear and frequently repeated. In response to the increasing discomfort of sociolinguists with notions like bilingualism, multilingualism and code-switching - notions that point to the transgression of language norms while at the same time maintaining the premise of a norm, a single unitary bounded language - the authors focus rather on the 'ordinary' multilangaging activities of the city. Shifting the focus away from relations between languages, or from how different languages are deployed in particular domains (demolinguistic mapping), or from how the individual is a container of various languages (p. 16), they propose a view of everyday language use in urban space which they call metrolingualism.

This is a 'non-count' approach to diversity, opposed to the 'mindset' of monolingualism. Polyglossia (or transglossia, or a host of other trans terms which have been mobilized for the last decades) is understood as a normal language practice, not a deviant one.
Central to the perspective is that these languages are deployed in specific contexts of urban space, and are implicated in activities germane to those spaces: languages emerge in the interrelationship between multitasking and linguistic resources, the intricate patterning of movement, activity and semiotic resources. As the authors explain: "[...] Language does not just happen against an urban backdrop, it is part of the city, the barber shop, the market garden, the networks of buying and selling. [...] Language activities produce time and space" (p. 33).

The book is rich in variations and adumbrations of these themes: the ordinariness of language mixing, the imbrication of language and the urban setting, the creativity of speakers, the common rhythms of language and city life. Three main notions are introduced: metrolingual multitasking, spatial repertoires and metrolingua francas.

Lest the mood be considered too celebratory, one chapter focuses on the frictions caused by multilingualism and by the constraints imposed on language use. "Social spaces are shaped by speech, by what can and cannot be said in particular venues, by how things are said and by the way they are heard" (p. 85). But generally speaking, the mood of the book is upbeat. Part of the emphasis on 'ordinary' language comes with the choice of sites like markets, restaurants, etc. and its populations of 'ordinary' people - the workers who make these sites function. This focus adds political clout to the idea of metrolingualism. At the same time, however, the authors ask a pertinent question: why is multilingualism not a value, why is it not valued? (p. 169).

I was surprised not to see any references to the pioneering work of Louis-Jean Calvet on urban sociolinguistics and particularly marketplaces. And the editors did not catch the faulty: "language hales us" (p. 148).

The authors conclude by emphasizing the fact that the book has been a 'writing together,' an interwoven text, a work in progress. As a text that tries to capture the elusive, ephemeral, transitory life of words in the city, it will surely stimulate discussion in cultural geography, sociolinguistics... and translation studies.

SHERry Simon Concordia University, Montreal, Canada 